\title{
遊走腎の診断に関する補遺
}

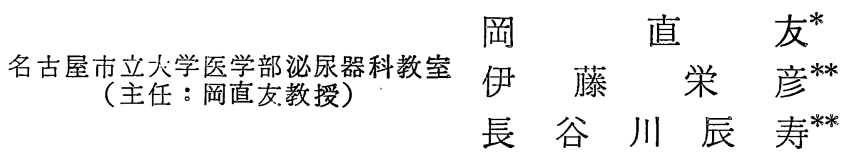

\section{SOME CONTRIBUTIONS TO DIAGNOSIS OF MOVABLE KIDNEY}

\author{
Naotomo Oka, Hidehiko Ito and Tatsuji Hasegawa \\ From the Department of Urology, Nagoya City University Medical School \\ (Dirctor: Prof. N. Oka)
}

Normal and physiological position of the kidneys was studied by pyelogram teken in the supine (in 474 cases) and erect (in 163 cases) positions. The following results were obtained.

1) The center of the pyelogram of the right side in the supine position is at the level of the second lumbar vertebra, and that of the left side is located by less than one half of the lumber vertebra higher. No sex difference was noted herein.

2) The center of the renal pelvis in the erect position was lower than that in the supine position by one vertebral height on both sides in male and on the left in female. On the right side in female it may descend even by one and a half vertebral height.

3) The inclination of the longitudinal axis of the kidney against the vertebra was less than $120^{\circ}$ in the supine position. In erect position the inclination reduces at most to $0^{\circ}$ on the left side, while on the right it may reduce further even to minus angle (upwards opened angle), but not to more than $-20^{\circ}$.

4) The kidney rotates around the renal pedicle during the erect podition, but not more than $35^{\circ}$.

5) The kidney which migrates or rotates beyond the overmentioned range is estimated to be pathologic and is rightly called "movable kidney".

Abdominal or loin pain was complained more often ( 2 to 3 folds) in movable kidney than in the normal one. Ptosis of the stomach was noticed in about one half of the cases of movable kidney. Infection of the upper urinary tracts occurred in higher frequency than in the normal Urinary stagnation, mostly of slight degree, in the renal pelvis (hydronephrosis) was encountered in 13.3 per cent of 323 cases of nephroptosis. Hydronephrosis of A grade was found in 2 per cent and Narath's symptom in 13.6 per cent of cases.

For the diagnosis of movable kidney non-compressing intravenous pyelography provides the best information, as it represents the most physiological condition. To be sure of obtaining enough films for diagnosis it is recommended to take films in the erect position at first, 5 minutes after intravenous injection of the contrast medium, followed by taking films in the supine position.

We have obtained excellent films by this method in 80 per cent of cases, while in 30 per cent, at most, in which the pyelography in the erect position was made after that in supine position.

\section{はばめに}

遊走腎とは生理的範囲を越えて腎が下垂する状態を名 付けるとはいうものの，生理的範囲について諸家の見解 は必ずしも一致していない。殊に立つて歩き，行動する 健康人のその場合の生理的に正常な位置は何処であろう

*教授, **助手

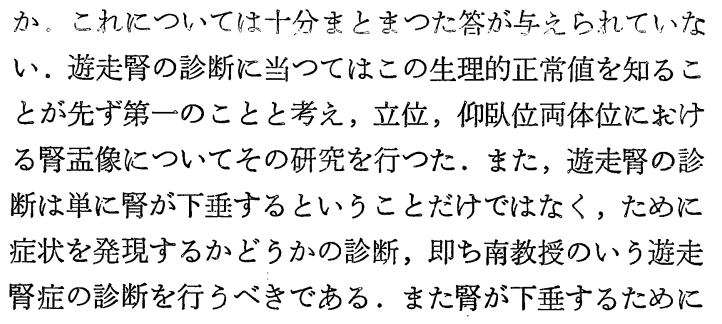


重要な合併症が起るかどらかを診断すべきである。これ らの点にも目を向けて統計的研究を行つた.

\section{研究成績}

\section{1）腎の位置の診断法}

下垂した腎であつても触診的に常に腎の位置が確認さ れるとは限らない，したがつて，腎位置を的確に把握す るためにはX線的に腎孟像を以てするのが最もよい. 腎 影自身は必ずしも得られるとは限らないからである。な 抢仰臥位，立位に和ける腎位置を比較検討するには腎孟 下極の位置を以てするよりも腎孟像の中心を以てするの がよいと思う．普通の場合ならよいが，腎が強く下垂す るときは，腎盂像下端は骨盤骨と重つたり或は腎の施回 と共に背柱と重つて, 私らが用いる経静性腎孟撮影法に よるときは，腎下極が見にくいことがしばしばあるから である。腎盂撮影法としては無圧迫性経静脈性腎盖撮影 法がよいと考光る。本法では必ずしも腎孟像の全体を十 二分に描出し得るとは限らぬといら久点はあるが, 腎典 像の中心を知るには事欠かない，また無圧迫性に施行す ることが最も生理的な自然の状態を描出し得るからであ る. 近年の造影剤の進歩によつて仰臥位撮影では無圧迫 性経静脈性腎孟撮影法で十分満足すべき腎盖尿管像を得 るよらになつたが，立位撮影を行らときはその像は十分 満足されるものが少く, この点は研究工夫を要する所で ある.私らはこれについても研究したので以下に述べる. 腎位置を示すには標準を腰椎骨にとるのが最もよく，腎 の下垂の程度も椎骨の高さと比べてあらわすのがよいと 思う。仰臥位, 立位の両撮影に際して, 撮影条件を注意 しても，撮影装置を異にするときはX線フィルム上の像 の大さは同一ではないことが多いから，寸法を以てそれ を表すのはむしろ䛊謬を招くからである．

要するに私らの研究においては腎位置をあらわすには 無圧迫性経静脈性腎盂撮影法によつて得たフィルム上の 腎孟中心の位置を腰椎を標準としてあらわす方法をとつ た。

2）遊走腎の診断法としてての無圧迫性経静脈性腎孟撮 影法

立位に和いて遊走腎の診断上満足すべき腎盃像を得ん として行つた研究成績を記す。当教室で筧は Maxwell らにならつて, 腎機能の screening test としての rapidsequence intravenous pyelography (rsp)を追試研究し, その成績を第15回日本泌尿器科学会中部連合地方会 (昭 和39年）に報告した。この研究に当り立位にてこの撮影 法を施行し在来にない良好な立位腎盕像を得ることに成
功し，それを併せて述べた。当教室ではその後立位 rsp のこの成績をヒントとしその応用法を行つて立位無圧迫 性経静脈性腎孟撮影法に於て高率に良好な腎孟像を得る ようになり，それを常套の撮影法としているので，以下 にこれらの点について述べる. 当教室で筧が rsp を立位 撮影に用いた当初は, 撮影対象の大部分が外来患者であ たため, 患者の最も協力を得易い簡易な方法を選び, 前 処置として，1)撮影前12～16時間絶食, 2)撮影前日ガス コン 12 錠投与, 3)ョード過敏症検査, の 3 者を行つた. 撮影は患者を立たせるか坐らせたままに76\% Urografin $40 \mathrm{cc} 30$ 秒以内に肘静脈より注入した. 急速注入の困難 な例には造影剂を 2 等分して, 左右の肘静脈から同時に 注入した. 注入開始時からかぞえて1分, 2 分, 3 分, 4 分, 5 分後に撮影を行い, 然る後に仰臥位に体位を変 換して注入開始時より15分ないし20分のフイルムを得 た、悪心を来たしたものが少数例あるほかには重篤な副 作用はなかつた。

立位 rsp を行つた19例の腎孟像の概要は次の如くであ る.11)造影剤静注開始の 2 分後に既に腎杯像の暗示され る症例もあるが, この時点では腎盂像としてはすべて不 十分である.2)静注後 3 分に至ると多くの症例に美麗な 腎孟像が得られるのであつて，19例中 7 例 $(36.8 \%)$ に は極めて鮮明で完全な腎孟像が得られ且つそのうちの 3 例には尿管もまた鮮明に描出されている（写真 $1 ， 2$ ). 完全な像とはいえなくても腎㙉或は尿管の形（走行・ 昖張の有無）を知るには十分なフイルムを数劣れば 14 例 $(73.2 \%)$ 飞は腎孟像までが，6例 (31.6\%) には腎 盕・尿管像共に描出されている. 3 )静注後 5 分のフイル ムでは，優秀美麗な腎盂像を得たものは，この時点で撮 影の行なわれた18例中に 8 例 $(44.4 \%)$ あり，尿管像を 共に得たものは 4 例 $(22.2 \%)$ ある. 遊走腎の診断上満 足のできるフイルムの得られたものを数えると, 腎孟像 までは18例中17例 $(94.4 \%)$, 汖腎像をむ併せるときは 9 例 (50\%) といら成績である.4) 静注後 3 分か 5 分の何 れかのフイルムに診断上満足すべき腎孟像を得たものは 19例中18例 $(94.7 \%)$, 腎盐・尿管像を共に得たものは13 例 $(68.4 \%)$ である. 即ち立位 rsp によつても，尿管ま でをも十分に描出せんとするためにはなお十分であると いえないが，腎孟像を中心とした遊走腎に関連する諧種 の変化を知るには本法は大部分の症例に対して満足すべ き腎孟像を提供するのである.

私らは過去においては無圧迫性経静脈性腎孟撮影法に よつて遊走督を診断しょうとするとき, 先ず仰卧位撮影 
写真1 Rapid-sequence intravenous pyelography による立位, 仰臥位における腎孟尿管像 26才女子
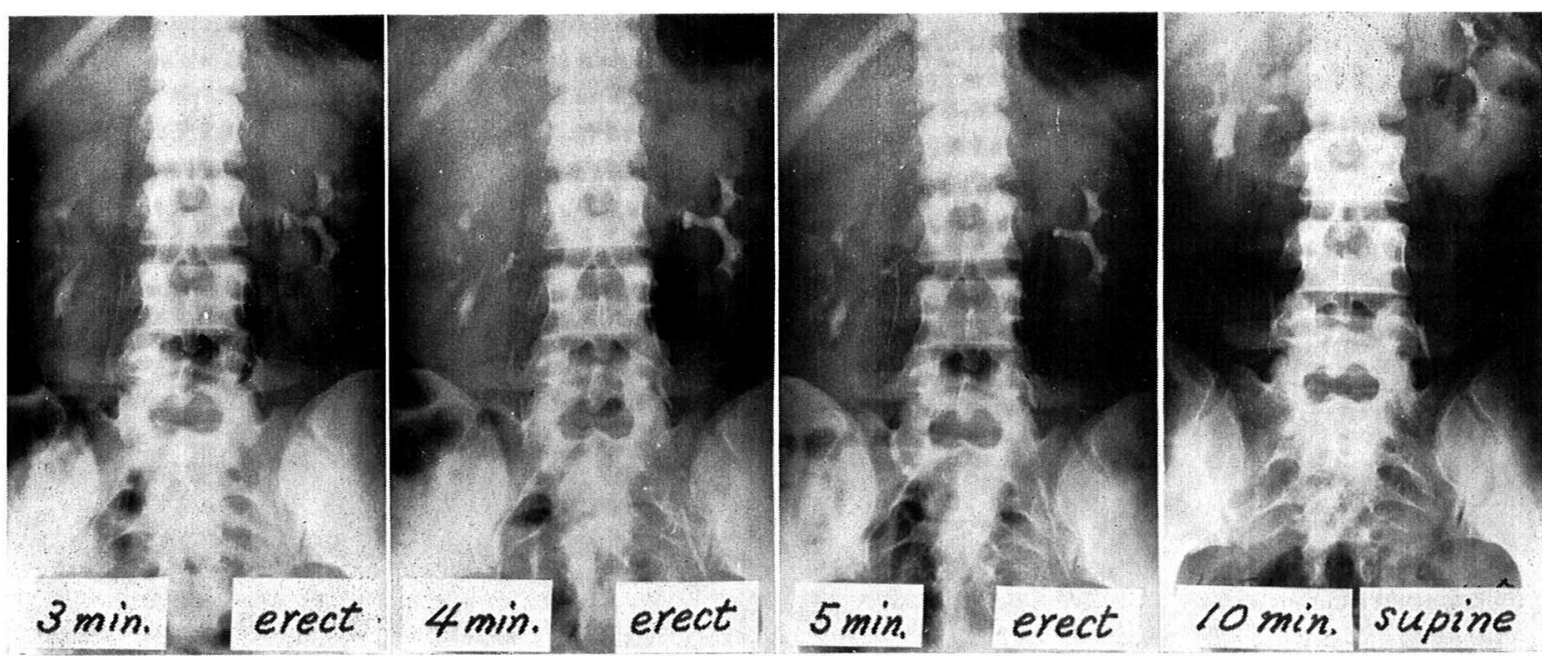

写真 2 同前. 21才女子

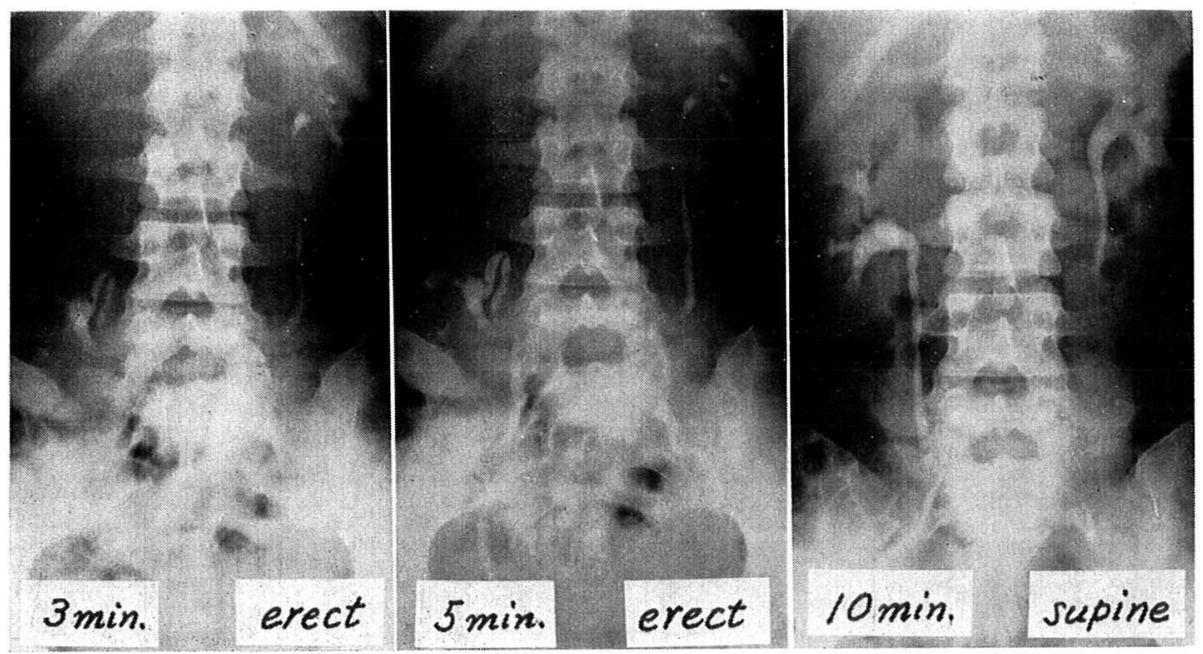

を行い然る後，多くは静注10〜15分後，立位撮影を行つ ていたが，これによつて後者の場合満足すべき腎盂像の 得られることが少かつた。立位 rsp の成績にヒントを得 てその後は造影剤静注後立位撮影を先行することにした が，これによつて多くの場合満足すべき立位像が得られ ている，この方法は，仰臥位にて造影剤の静注を可及的 速に行い, 1 分前後副作用の有無を観察して後立位をと らせて静注後 5 分に撮影を行い, 然る後再び仰臥位とし て静注後10分ないし15分のフィルムを得るのである，造 影剂としては76\% Urografin40ccを用いるのを普通とす るが, $20 c c の$ 使用でも余り遜色のない腎盂像が得られる.
無圧迫性経静脈性腎盂撮影法による腎盂像描出の鮮・ 不鮮には個人差があるので，批判上の誤差を少くするた めに, 上述の腎盂撮影法によつて造影剤静注後10分ない し15分に得られた仰臥位腎孟像の鮮明であつた 104例に ついて，それに先行する 5 分時の立位腎盂像の描出成績 をみると第 1 表の如くである。上部尿路全般が判明に描 出されたものは36例（34\%）に過ぎないが，遊走腎に関 連した上部永路の変化を判断するに十分な腎盂像の得ら れたものは50例 $(48 \%)$, 腎孟腎杯像のみを対象とするな ら86例（83\%） 飞满足すべき立位腎需像が得られてい る、これと反対に, 造影剂静注後 5 分ないし10分で先ず 
第 1 表 立位に拈ける 5 分像の描出成績

\begin{tabular}{|c|c|c|c|}
\hline 珡 杯 & 腎 罝 & 尿管 & $\begin{array}{l}\text { 例 数 } \\
(104 \text { 例 })\end{array}$ \\
\hline$H$ & $H$ & $H$ & $36^{*} \triangle$ \\
\hline$H$ & H & + & $8 * \triangle$ \\
\hline$H$ & $H$ & \pm & $16 \triangle$ \\
\hline H & H & $=$ & $9 \triangle$ \\
\hline$H$ & + & - & $1 \triangle$ \\
\hline$H$ & \pm & H & 2 \\
\hline H & \pm & \pm & 1 \\
\hline$H$ & - & H & 1 \\
\hline$H$ & - & - & 6 \\
\hline+ & H & H & $4^{*} \triangle$ \\
\hline+ & H & \pm & $1 \triangle$ \\
\hline+ & $H$ & - & $5 \triangle$ \\
\hline+ & + & $H$ & $1^{*} \triangle$ \\
\hline+ & + & + & $1 * \triangle$ \\
\hline+ & + & - & $4 \triangle$ \\
\hline+ & \pm & \pm & 1 \\
\hline+ & - & - & 2 \\
\hline \pm & \pm & \pm & 3 \\
\hline- & - & - & 2 \\
\hline
\end{tabular}

H：像の全景がよくめらわれたもの

十：全景は十分にあらわれないが, 形態の推測 判断は十分にできるもの

士：暗示的に描出されたもの

*：腎杯・腎㙉・尿管の全部を明かにし得るむ の (50例， $48 \%)$

$\triangle$ : 腎杯・腎孟像を明かにし得るもの（86例， $83 \%$ )
第 2 表 仰臥位撮影の先行した場合の立位像の描出成績

\begin{tabular}{|c|c|c|c|c|}
\hline $\begin{array}{l}\text { 仰臥位撮影後立 } \\
\text { 位撮影されるま } \\
\text { での時間 }\end{array}$ & 腎杯 & 腎孟 & 尿管 & $\begin{array}{c}\text { 例 数 } \\
(19 \text { 例 }\end{array}$ \\
\hline 2分 & $\begin{array}{l}+ \\
\pm\end{array}$ & $\overline{ \pm}$ & - & $\begin{array}{l}1 \\
1\end{array}$ \\
\hline 3分 & $\begin{array}{l}H \\
\text { H } \\
\pm \\
\pm\end{array}$ & $\begin{array}{l}\frac{H}{ \pm} \\
\pm\end{array}$ & $\begin{array}{l} \pm \\
\pm \\
+\end{array}$ & $\begin{array}{l}1 * \Delta \\
1 \\
1 \\
2\end{array}$ \\
\hline 5分 & $\begin{array}{l}\text { H } \\
\text { H } \\
\text { H } \\
+ \\
\pm\end{array}$ & $\frac{H}{+}$ & $\begin{array}{l}\frac{H}{ \pm} \\
\pm \\
-\end{array}$ & $\begin{array}{ll}3 * & \triangle \\
1 & \triangle \\
1 & \\
1 & \triangle \\
3 & \end{array}$ \\
\hline 10 分 & $\begin{array}{l}+ \\
+ \\
\pm\end{array}$ & \pm & \pm & $\begin{array}{l}1 \\
1 \\
1\end{array}$ \\
\hline
\end{tabular}

附号は前表に同じ

$$
\text { * : } 4 \text { 例 }(21 \%) \triangle 6 \text { 例 }(32 \%)
$$

行つた仰臥位腎孟像の明瞭に描出された19例について， その後に立位撮影を行つた場合の立位腎盂像描出成績は 第2表に示すが如くであつて，遊走腎の診断上満足すべ き像の得られたものは, 上部尿路像全般については 4 例 $(21 \%)$,腎㙉腎杯像のみについては 6 例（32\%）に過ぎ ない。

かくの如く 2 つの場合を比較してみると，遊走腎の診 断の目的で無圧性経静脈性腎孟撮影法によつて立位腎孟 像を得んとする場合には，立位撮影を先行するのが成果 を収めることの大きいことがわかる，一二の例を示すと 写真 3 及び 4 の如くである.

写真 3 立位撮影を先行した場合の遊走腎に打ける無圧性経静脈性腎孟尿 管撮影像 28才男子, Narath 氏症候をみる。

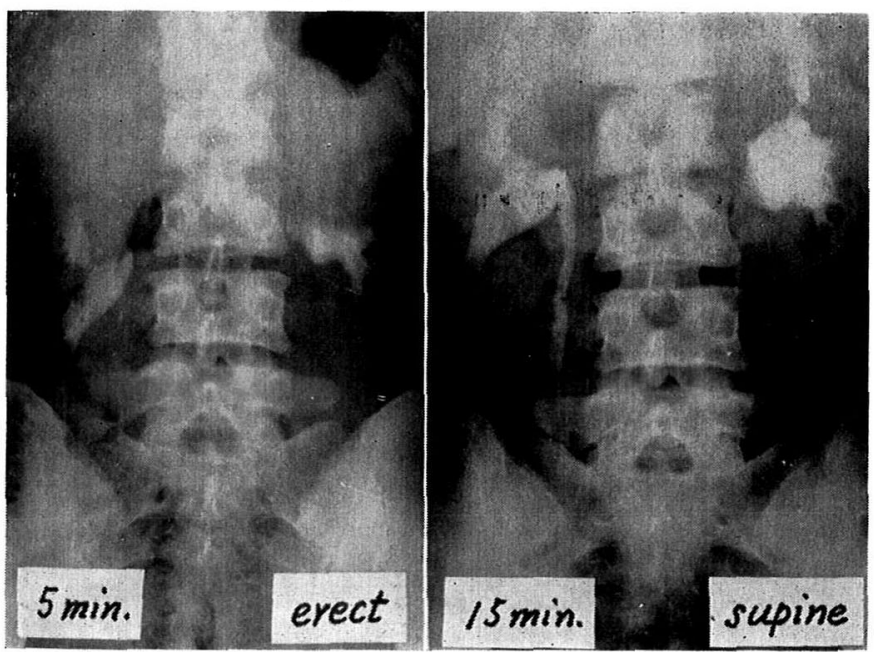


写真 4 同前. 30 才女子

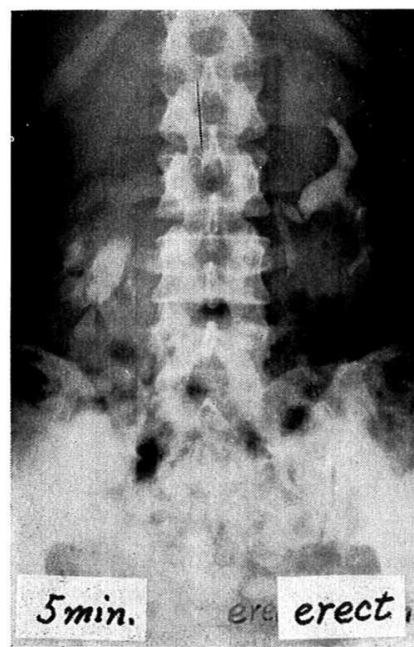

3）正常者に括ける腎盂像中心の位犆

主として無圧迫性経静脈性腎孟撮影法により，一部に は逆行性腎需撮影法によるものを含めて，過去 5 年間に 撮影したフイルムから, 腹痛・腰痛のよらな遊走腎に関 係のある症状をもたない撮影例（以下これを正常者と呼 ぶ）について揭題の研究を行つた．管球焦点は䏴に置い て撮影を行つた。

a ）仰臥位

正常者から任意に選んだ 474例の仰卧位における右側 腎衁像中心の位置を腰椎骨像を標準にして記載すると第 3 表の如くである. 年令は17才より57才に亘つている. 腎盂中心の位置の頻度は性, 年令によつて差がないので 一括表記した。

第 3 表 正常者の右側腎盂像中心の位置の分布

\begin{tabular}{|c|c|c|c|c|c|}
\hline 腰椎の高さ & $\mathrm{L}_{1}$ & $\mathrm{~L}_{1-2} \mathrm{~L}_{2}$ 上 $\mathrm{L}_{2}$ 中 $\mathrm{L}_{2}$ 下 & $\mathrm{L}_{2-3}$ & $\mathrm{~L}_{3}$ & $\mathrm{~L}_{4}$ \\
\hline $\begin{array}{c}\text { 男 } \\
290 \text { 例 }\end{array}$ & 16 & 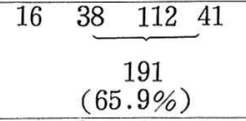 & 27 & 26 & 14 \\
\hline 㚣 & 14 & $10 \underbrace{33 \quad 62}_{\begin{array}{c}118 \\
(64.1 \%)\end{array}} 23$ & 20 & 16 & 6 \\
\hline
\end{tabular}

右側腎孟像の中心は男女共に第 1 腰椎骨から第 4 腰椎 骨の高さに亘つているが，第 2 腰椎骨中央の高さに偏移 のけわしい峰がある.これをも少うし分けて観察すると, 第 2 腰椎のいずれかの部分に腎㙉像中心が対応するもの が男女それぞれ 191例 $(65.9 \%) ， 118$ 例 $(64.1 \%) ， 己$

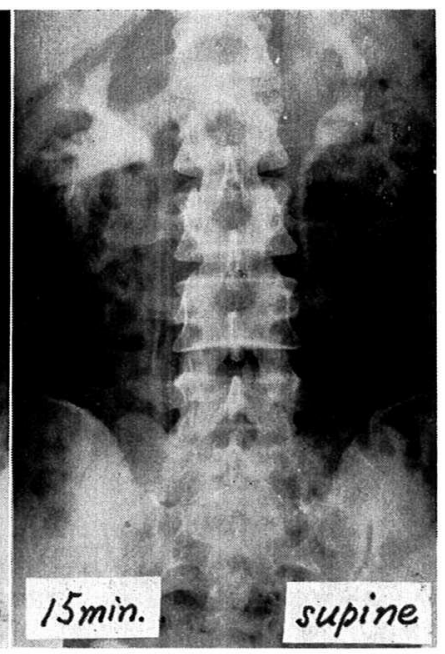

れより上方にあるものは男子 32 例 $(11.0 \%)$ ，女子 42 例 (22.8\%),下方にあるものは男子 67 例 $(23.1 \%)$,女子 42 例 $(22.8 \%)$ である。こうしてみると第 2 腰椎骨の高さ といらのが仰卧位に拈ける右側腎孟像の基準の位置であ るといらことができる．

左側に拈いては腎需像の中心は右側と同高かあるいは 半腰椎高だけ高位にある。

b ) 立位

正常者において立位腎盂像を得た 163例の仰臥位から 立位に変換した場合の腎孟像中心の下垂の大さを示すと 第 4 表の如くである.

第 4 表 正常者の立位に扣ける腎孟中心の下垂の大きさ （椎骨高を以てむらわす）

\begin{tabular}{|c|c|c|c|c|c|c|c|}
\hline $\begin{array}{c}\text { 下垂の大きさ } \\
\text { (椎骨高) }\end{array}$ & 0 & $<\frac{1}{2}$ & $<1$ & $1 \frac{1}{2}$ & $<2$ & $<2$ \\
\hline 右 & $\begin{array}{c}\text { (20男 } \\
\text { (20例) }\end{array}$ & 2 & 5 & 7 & 5 & 1 & \\
\hline $\begin{array}{c}\text { 女 } \\
\text { 側 }\end{array}$ & 1 & 6 & 32 & 19 & 11 & \\
\hline 左 & $\begin{array}{c}\text { (18例) } \\
\text { (18例) }\end{array}$ & 0 & 7 & 8 & 2 & 1 & \\
\hline $\begin{array}{c}\text { 女 } \\
\text { (57 例) }\end{array}$ & 1 & 11 & 30 & 10 & 4 & 1 \\
\hline
\end{tabular}

下垂の大さは椎骨高を以てあらわし, この際連続する 2 つの椎骨の相同の部分の間の距離（例えば第 2 腰椎・ 第 3 腰椎の上縁間の距離）を以て 1 椎骨高とした。した がつて本論文に拈ける椎骨高は一椎骨の厚さよりは厚 く, フイルムの計測の平均值からみて, 椎間距離は椎骨 
の厚さの約 $1 / 3$ の高さをるつているから，それ丈長い訳で ある。

男女，左右を通じて $1 / 2 \sim 1$ 椎骨高の下垂をみるものが 最も多いが，男子ではここにけわしい偏移の峰はつくら ぬに反し女子ではややけわしい峰を作つている。体側に 分けて観察すると，左側では立位に和ける腎下垂が 1 椎 骨高までのものが男子15例 (83.3\%)，女子42例（73.7 \%) であつて 1 椎骨高までの下垂が正常者の基準と考克 られる。即ち腎盂像の中心が第 3 腰椎の半ばまでの高さ にあるものが生理的正常な状態とい光る。しかし，右側 に括いては 1 椎骨高の下垂者は男子では14例（70\%)で, これを基準とするにはばからぬが，女子では39例（57.4 \%) 即ち半数を僅に上迴つた頻度であつて, 上述の如く 偏移の峰といら点からは一とまず基準と考えてもよい が，生理的に正常なる限界と考寽るにはいささか抵抗を 感ずる。1 $1 \frac{1}{2}$ 椎骨高までの下垂者を拾光ば研究対象例の $83.3 \%$ こここに含まれるのである。

要するに，立位に执いて腎孟像中心は 1 腰椎高までの 下垂を来たすのが正常者の基準と考えることができる． 即ち，立位腎盂像のみについていえば腎孟像中心は右側 では第 3 腰椎の何れの部分かの高さにあり, 左側ではこ れより半椎骨高いのが正常者の基準であるということが できる，ただ女子の右腎に秃いては，生理的正常なる下 垂の限界を $11 / 2$ 腰椎高まと見なしても不合理ではないと いえると思う。

4）正常者に和ける腎縦軸の傾斜

a ) 仰臥位

昭和41年に得たフィルムについてみると，右側 143例 （男子36例，女子 107例）の うち腎長軸（上腎杯上端 から下腎杯下端を結ぶ線を以て表した）が脊柱に対して 下方に開いた $10^{\circ}$ の傾斜をとるものが最も多い（29例： $27.1 \%$ ）之はい光，傾斜角度分布は広く $0^{\circ} \sim 20^{\circ}$ V亘 るものが96例 (89.7\%) ある。左側 131例（男子35例， 女子96例）についてみると，10ㅇ傾斜をるつるのが最 も多く（34例：35.4\%） $10^{\circ} \sim 20^{\circ}$ の範囲に互るものが 84例（87.5\%）を算する。したがつて脊柱に対して $20^{\circ}$ までの傾斜をとるのが左右共に正常者の基準と考光るこ とができる。

この傾斜を腎の位置によつて分けて観察すると，右側 そおいては，腎孟像の中心が第 2 腰椎を越えないものは 61例中 46 例 $(75.4 \%)$ 飞打いて $5^{\circ} \sim 20^{\circ}$ の傾斜をとるに 対し，腎孟像の中心が第 3 腰椎以下にあるものでは44例 中28例 $(63.6 \%)$ が $0^{\circ} \sim 10^{\circ}$ の傾斜をとつている。即ち
腎位置が下方にある程腎縦軸の脊柱に対する傾斜角は小 さくなるのであつて，これは腎が下垂する際に腎動脈起 始部を中心として腎径を半径とする円周_上に移動するた めに当然の結果である．このことは立位に際してょり著 明に認められる，左側に打いても同様であつて，腎孟像 の中心が第 2 腰椎を越えないものでは大部分（78例中68 例 : $78.2 \%$ ）が $10^{\circ}$ 〜 $20^{\circ}$ の傾斜を，第 3 腰椎以下にある ものでは大部分（18例中 15 例： $83.3 \%$ ) が $5{ }^{\circ} \sim 15^{\circ}$ の傾 斜をとつている。

b ) 立位

立位に打ける腎縦軸の脊柱に対する傾斜は第 5 琵に示 す如くである。ここに負の角度は腎縦軸と脊柱とのなす 角が上方に開いている場合をあらわす。

第 5 表 立位における腎縦軸の脊柱に対する傾斜角

\begin{tabular}{|c|c|c|c|c|c|c|c|c|}
\hline 体側 & $\begin{array}{l}\text { 腎孟像 } \\
\text { 中心の } \\
\text { 位置 }\end{array}$ & 性別 & $\begin{array}{c}-50^{\circ} \\
< \\
\end{array}$ & $\mid \begin{array}{c}-50^{\circ} \\
\sim-20^{\circ} \\
-\end{array}$ & & $\begin{array}{l}1^{\circ} \sim \\
10^{\circ}\end{array}$ & $\begin{array}{c}11^{\circ} \\
20^{\circ} \\
\end{array}$ & $20^{\circ}$ \\
\hline \multirow{4}{*}{$\begin{array}{c}\text { 右側 } \\
\text { 例) }\end{array}$} & \multirow{2}{*}{$\mathrm{L}_{2}$ 以上 } & 男 & & & 1 & 3 & 2 & 2 \\
\hline & & 女 & & & 2 & 1 & 2 & \\
\hline & \multirow{2}{*}{$\mathrm{L}_{3}$ 以下 } & 男 & & 3 & 13 & 10 & 2 & \\
\hline & & 女 & 4 & 14 & 38 & 28 & $\overline{4}$ & \\
\hline \multirow{4}{*}{$\begin{array}{c}\text { 左側 } \\
(127 \\
\text { 例) }\end{array}$} & \multirow{2}{*}{$\mathrm{L}_{2}$ 以上 } & 男 & & & 1 & 12 & 6 & \\
\hline & & 女 & & & 2 & 19 & 9 & \\
\hline & \multirow{2}{*}{$\mathrm{L}_{3}$ 以下 } & 男 & & & 3 & 10 & 2 & 1 \\
\hline & & $\overline{\text { 女 }}$ & & 1 & 7 & 45 & 9 & \\
\hline
\end{tabular}

第 6 表 正常者の右側の腎縦軸の脊柱に対する傾斜 (角) の变化

\begin{tabular}{|c|c|c|c|c|c|c|}
\hline 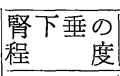 & 性別 & $0^{\circ}$ & $\begin{array}{l}10^{\circ} \\
\text { 以下 }\end{array}$ & $\begin{array}{l}20^{\circ} \\
\text { 以下 }\end{array}$ & $\begin{array}{l}30^{\circ} \\
\text { 以下 }\end{array}$ & $\begin{array}{l}30 \sim 0^{\circ} \\
70^{\circ}\end{array}$ \\
\hline \multirow{2}{*}{$\begin{array}{c}1 \text { 椎骨高 } \\
(75 \text { 例 })\end{array}$} & 男 & 1 & 10 & 8 & 4 & 0 \\
\hline & 女 & 7 & 16 & 18 & 7 & 4 \\
\hline \multirow{2}{*}{$\begin{array}{c}1 \frac{1}{2} \\
\text { 椎骨高 } \\
(27 \text { 例 })\end{array}$} & 男 & 0 & & 2 & 2 & \\
\hline & 女 & 0 & 11 & 5 & 2 & 5 \\
\hline \multirow{2}{*}{ 計 } & 男 & 1 & 10 & 10 & 6 & 0 \\
\hline & 女 & 7 & 27 & 23 & 9 & 9 \\
\hline \multirow{2}{*}{\begin{tabular}{|c|} 
热以上 \\
$(27$ 例 $)$
\end{tabular}} & 男 & & & 1 & & \\
\hline & 女 & 1 & 4 & 5 & 9 & 7 \\
\hline
\end{tabular}

右側では負の角をとるものが男女併せて研究対象例の $65.9 \%$ むるのに，左側では $11.0 \%$ に過ぎない，腎の位 置が低い程負の角をとるものの頻度が増していることが 表かららかがえる，腎は立位をとるとその位置が下ると 同時に腎茎基部を中心に廻軸するが，その程度は右側に 於て遙に大なることが知られる。

仰臥位から立位に変換した場合の腎縦軸の脊柱に対す 
る傾斜の変化を右側のみについてみると第 6 表の如くで ある。既述の如くして，正常の基準と考光られる 1 椎骨 高以内の腎下降者では男女併せ て75例中58例（77.3） が，また生理的な下降限界之許容され得る $11 / 2$ 椎骨高ま での下降者では 102 例中 76 例 $(74.5 \%)$ が $20^{\circ}$ 以下の傾 斜の変化（傾斜角の減少）に止つている。したがつて $20^{\circ}$ を正常者に拈ける立位に変換時の傾斜角変化の基準 と考えることができる．立位に括ける腎の下垂が $111 / 2$ 椎 骨高を越光るものに於ては，傾斜角の変化はこれより大 きくなるものが多い.

要之，腎縦軸の脊椎に対する傾斜の正常者としての基 準は，仰臥位においては $20^{\circ}$ であり，立位においては左 側はこれより小さいが負の角にはならず。右側では負の 角をとり得るがそれる $20^{\circ}$ までといらことができる。 た，仰臥位から立位に変換した場合 $20^{\circ}$ の角の変化を来 すといらのが正常者の基準とすることができる。

5）立位に乱る腎の腎茎周囲の迴枟

ほとんぞ同じ条件で撮影された10数枚のフィルムか ら，仰臥位・立位両体位に打政㹂像の縦径を測り， 腎が仰臥位に扔いては水平線に対して $10^{\circ}$ 傾斜している と仮定して（これは $3 〜 4$ 枚の正側位像から得た傾斜の 概要である),仰臥位から立位に変換した際の腎の腎径周 囲の迴転を椎算すると， $35^{\circ} \mathrm{C}$ 以内の迴転に止まるのが大 勢を占めるのであつて, これが正常者の基準といらこと ができる。

6）腹痛・腰痛者に和ける腎位置・迴転の正常者との 比較

結石等の如き他に症状を発現する器質的疾患が認めら れずに腹痛・腰痛を訴兄る患者（以下有症状者と呼ぶ） について上述諸点が正常の基準を逸脱する頻度がどの位 あるかを統計的に研究し，これを正常者と比べてみた所 を述べる。な怙この研究は遊走腎の頻度の多い右側につ いてのみ行つた。

a ）仰臥位に抢ける腎盂中心の位置

仰臥位に䑙ける腎盂像中心の位置が第 2 腰椎を越えて 下方にあるものの遭遇頻度を正常者と有症状者の間で比 較すると第 7 表の如くである。表に，1 月以上に亘る 有症状者とそれ以内の期間のものを分けたのは，前者に 遊走腎による症状である可能性が大きく，後者では他の 佩発的症状である可能性があり得ると考光たからであ る。結果はこの両者間に遭遇頻度に著差がないが，後者 に多少頻度が大きくあらわれている。目立つことは正常 者と有症状者との間には遭遇頻度にかなりの差があるこ
第 7 表 右腎下垂者の，無症候者有症候者における 遭遇頻度の比較

（腎孟中心が第 2 腰椎を越えて下方にあるもの）

\begin{tabular}{|c|c|c|c|}
\hline 性別 & 無症候者 & $\begin{array}{l}1 \text { 月以上に亘 } \\
\text { る有症候者 }\end{array}$ & $\begin{array}{c}1 \text { 月以内の } \\
\text { 有症候者 }\end{array}$ \\
\hline 男 & $\begin{array}{r}290 \text { 例中 } \\
23.1 \%\end{array}$ & $\begin{array}{l}15 \text { 例中 } \\
53.3 \%\end{array}$ & $\begin{array}{l}11 \text { 例中 } \\
54.5 \%\end{array}$ \\
\hline 女 & $\begin{array}{r}184 \text { 例中 } \\
22.8 \%\end{array}$ & $\begin{array}{l}80 \text { 例中 } \\
41.2 \%\end{array}$ & $\begin{array}{l}20 \text { 例中 } \\
50.0 \%\end{array}$ \\
\hline
\end{tabular}

第 8 表 立位をとつた時の右下腎垂者の出現頻度の比較

\begin{tabular}{|c|c|c|c|c|}
\hline $\begin{array}{l}\text { 腎孟像中心 } \\
\text { 中垂の大 } \\
\text { きさ作 }\end{array}$ & 性別 & 無症候者 & $\begin{array}{l}1 \text { カ月以上 } \\
\text { に亘る有症 } \\
\text { 候者 }\end{array}$ & $\begin{array}{l}1 \text { 力月以内 } \\
\text { の有症候者 }\end{array}$ \\
\hline \multirow{2}{*}{$\begin{array}{l}1 \text { 椎骨高を } \\
\text { 越えるもの } \\
\text { 全般 }\end{array}$} & 男 & $\begin{array}{l}20 \text { 例中 } \\
30.0 \%\end{array}$ & $\begin{array}{r}7 \text { 例中 } \\
28.6 \%\end{array}$ & $\begin{array}{l}13 \text { 例中 } \\
30.8 \%\end{array}$ \\
\hline & 女 & $\begin{array}{l}69 \text { 例中 } \\
43.5 \%\end{array}$ & $\begin{array}{l}71 \text { 例中 } \\
53.5 \%\end{array}$ & $\begin{array}{l}\text { 18例中 } \\
38.9 \%\end{array}$ \\
\hline \multirow{2}{*}{\begin{tabular}{|l|}
$1 \frac{1}{2}$ 椎骨 \\
高を越える \\
ものみみ
\end{tabular}} & 男 & $\begin{array}{l}20 \text { 例中 } \\
5.0 \%\end{array}$ & $\begin{array}{r}7 \text { 例中 } \\
12.9 \%\end{array}$ & $\begin{array}{r}13 \text { 例中 } \\
0 \%\end{array}$ \\
\hline & 女 & $\begin{array}{l}69 \text { 例中 } \\
17.4 \%\end{array}$ & $\begin{array}{l}\text { 71例中 } \\
26.8 \%\end{array}$ & $\begin{array}{l}\text { 18例中 } \\
33.3 \%\end{array}$ \\
\hline
\end{tabular}

とであつて，腹痛・腰痛を訴え，他に器質的疾患のない 患者の20～30\%においてはそれが遊走腎である可能性を 考えることができることを物語る．

b ）立位に和ける右腎の下垂

第 8 表にみられる如く，1 椎骨高以下の腎下垂者の頻 度は正常者。有症状者の間に大差はないが，1 1 12 椎骨高 以上下垂するものは有症者において正常者より遙に頻度 が高い。ある程度以上の腎下垂は症状発現とかなり密接 な関係のあるこことがわかる。

c）立位に括ける右腎の脊柱に対する傾斜角の変化 一と先ず基準と考える $20^{\circ}$ 以上の傾斜角の変化を来た したものについて記載すると第 9 表の如くである．ここ に乱いても，正常の基準以上に腎が迴転するものは正常 者より有症状者に遥に多いことが知られる。

以上を要するに，腎盂像中心の位置，立位に甜腎 下垂の大さ，その際の傾斜の変化のいずれの点において も，正常な基準を逸脱するものは正常者と比べて有症状

第 9 表 腎縦軸の脊柱に対する傾斜の変化の高 度なるのの出現頻度の比較 $\left(20^{\circ}\right.$ 以上の変化を来たすもの)

\begin{tabular}{|c|c|c|c|}
\hline 性別 & 無症候者 & $\begin{array}{l}1 \text { カ月以上に } \\
\text { 亘る有症候者 }\end{array}$ & $\begin{array}{l}1 \text { 力月以内の } \\
\text { 有症候者 }\end{array}$ \\
\hline 男 & $30.8 \%$ & $\begin{array}{l}5 \text { 例中 } \\
40.0 \%\end{array}$ & $\begin{array}{l}2 \text { 例 } \\
100 \%\end{array}$ \\
\hline 女 & $25.0 \%$ & $\begin{array}{l}26 \text { 例中 } \\
46.1 \%\end{array}$ & $\begin{array}{l}\text { 17例中 } \\
75.0 \%\end{array}$ \\
\hline
\end{tabular}


者に遙に多いことが知られる．したがつて，これらの正 常な基準を逸脱するといらことが症状の発現とかなりに 関連性があるということができる。しかし，無症状者で も正常の基準を逸脱しているものが少くないことにも注 意せねばならない。

6) 併発症・合併症

遊走腎の併発症の重きをなするのは内臟下垂であり， 遊走腎者にみられる症状の或るものは内蔵下垂による可 能性のあることは万人の認めるところである. しかし， 患者の訴える症状が真にそのいずれに起因するかを臨床 的に的確に定めることは困難乃至不可能である. 合併症 として，腎固定術適応の決定上重要なものは上部尿路の 感染と尿停滞であると考兵る。これは腎実質に直接危害 を及ぼすからである．以下，内臟下垂の代表例としての 胃下垂, 上部尿路感染及び上部尿路停滞についての及触 れてみる。

a ）胃下垂と腎下垂

本学放射線科教室の宮田助教授の協力を得て, 胃の仰 卧位・立位に和ける撮影を行い，立入教授の方法にした がつて，立位に括いて胃角が Jacoby 氏線以下に下降す るものを胃下垂，それ以上にあるものを正常として分類 した. かくして24例について右腎の下垂状態と胃下垂の 遭遇頻度を対比してみると第10表に示すが如くである。

第10表 腎下垂者と胃下垂者の頻度

\begin{tabular}{|c|c|c|}
\hline \multirow{2}{*}{ 腎盂中心の位置 } & \multicolumn{2}{|c|}{ 胃下垂の有無 } \\
\hline & 正 常 者 & 胃下垂者 \\
\hline $\mathrm{L}_{2}$ まで & 11 & 0 \\
\hline $\begin{array}{r}\mathrm{L}_{2} \text { を越え } \\
\text { るもの }\end{array}$ & 9 & 4 \\
\hline
\end{tabular}

腎（腎孟像中心）の位置が正常なものには胃下垂者が ないが，腎孟中心が第 2 腰椎以下にあるものにはその約 半数に胃下垂者をみている. 即ち，腎下垂と胃下垂は相 伴つてあらわれ易いが，他方腎下垂者の約半数には胃下 垂がないといらことが注目される。

更に，立位に打ける腎下垂の程度と胃下垂との関連性 をみたが，症例数が少いためか，24例の娭討からは，特 別な関連性を指摘できなかつた。

b ）上部尿路感染

腎下垂の程度と上部尿路感染を対比梌討した所を述べ る.ここでは敢て一一尿管カシーター法によつて腎尿を 採取することなく，尿路感染者で発熱をみるものは上部
尿路感染者であるという臨床的常識に則つてそのような 発熱者を拾いあげた.

昭和 $40 \cdot 41$ 年の 2 年間飞結核・結石・腫場の如き明ら かに指摘されるような疾患が腎・尿管にない者で，仰卧 位・立位の両フィルムの得られた 137例（すべて女子） についてみると，その 14 例に尿路感染による $38^{\circ} \mathrm{C}$ 以上の 熱発が来院を促す所以となつている。これを腎孟像中心 の位置ならびに立位における腎下垂の程度との関連下に 分けて観察すると第11表に示す如くである。

第11表 尿路感染による発熱者と腎下垂

\begin{tabular}{|c|c|c|c|}
\hline \multirow{3}{*}{ A } & $\begin{array}{l}\text { 仰臥位における } \\
\text { 腎孟中心の位置 }\end{array}$ & 無熱者 & 発 熱 者 \\
\hline & $\begin{array}{l}\mathrm{L}_{2} \text { 以上にある } \\
\text { もの }\end{array}$ & 73 & $5(6.4 \%)$ \\
\hline & $\begin{array}{l}\mathrm{L}_{2} \text { を越えて下 } \\
\text { 方にあるもの }\end{array}$ & 50 & $9(18.0 \%)$ \\
\hline \multirow{4}{*}{ B } & $\begin{array}{l}\text { 立位における } \\
\text { 腎下垂の程度 }\end{array}$ & 無熱者 & 発 熱 者 \\
\hline & 1 椎骨高まで & 59 & $8(11.9 \%)$ \\
\hline & 1 $\sim \frac{1}{2}$ 椎骨高 & 38 & $1(0.3 \%)$ \\
\hline & 2 椎骨高以上 & 27 & $5(18.5 \%)$ \\
\hline
\end{tabular}

仰臥位にて腎孟中心の位置の低いものには正常者にお けるより発熱を来たするのの多いこと，立位に甜ける腎 下垂の程度の大きいものの方が発熱者が多いことが注目 される，これ游走腎（腎下垂）飞和ける上部尿路停滞 とからんだ状態であると考えられる。

c ）腎孟の尿停滞

遊走腎において，殊に立位に際する腎下垂時に腎盂に 尿停滞を起し易いことは諸家の等しく指摘する所であ り，遊走腎と水腎の関係についても論ぜられる所が少く ない，腎下垂に伴ら尿管屈曲のために軽度一過性の腎盂 滞尿が起ることはうなずけるが，腎が単に下垂するとい らことだけで，著明な腎機能障害を伴うような水腎症を 起すことはそんなにしばしばあるものではない，当教室 で過去 5 年間に取扱つた腎孟撮影例について右腎の位置 と腎盂の尿停滞 (滞尿腎) の頻度的関係をみると第 12 表 の如くである．腎孟の尿停滞者は検査例 323 例の $13.3 \%$ にみられるが，これは腎孟のみに多少の拡張としてその 所見をみるだけであつて，腎杯には全く器械的影響を示 すような変化のないものが大部分である。やや程度が進 んで腎杯にも尿停滞像がみられるものでも私らの水腎の 分類にしたがえば $\mathrm{A}$ 程度に止るのであつて，そのような ものは僅に 7 例にみられたに過ぎない。最も顕著な例で 
第12表 腎孟中心の位置（仰臥位）と上部尿路 停激の頻度（右側について）

\begin{tabular}{|c|c|c|}
\hline $\begin{array}{c}\text { 㹂孟中心の } \\
\text { 位置 }\end{array}$ & 正常者 & $\begin{array}{l}\text { 尿停滞気味にあ } \\
\text { る者 }\end{array}$ \\
\hline $\mathrm{L}_{2}$ 以下 & 178 & $16(8.2 \%)$ \\
\hline $\mathrm{L}_{3}$ & 119 & $20(14.4 \%)$ \\
\hline $\mathrm{L}_{4}$ & 15 & $6(28.6 \%)$ \\
\hline 計 & 323 & $42(13.3 \%)$ \\
\hline
\end{tabular}

写真 5 著者らの遭遇した尿停演腎. 62 才女子, a. 仰臥位, b. 立 位

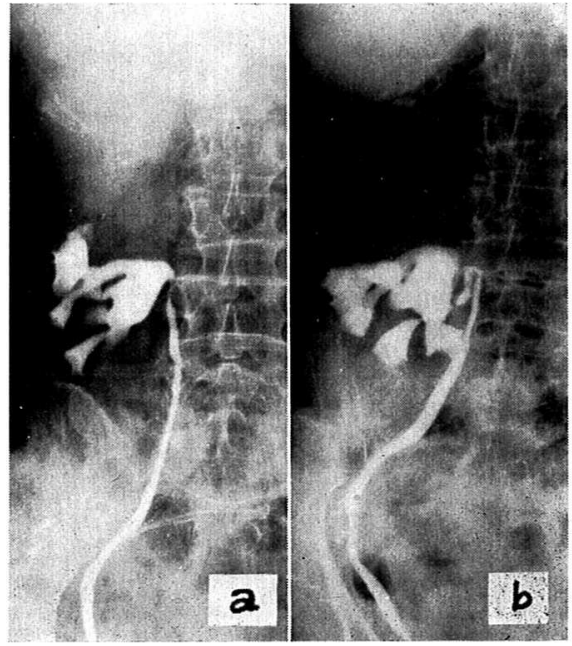

も写真 $5 \mathrm{a}, \mathrm{b}$ の如きものに過ぎない。なお゙，遊走腎者で 高度の水腎を呈するものがこの間に 2 例であつたが，手 術の結果それには異常血管の尿管起始部絞扼が主役を演 じていたので本論文の研究対象例中には算えていない. さて，このような滞尿腎の遭遇頻度を腎位置と対比して みると表から明らかなように腎位置の低いものほど頻度 が高い。このことは，腎下垂と腎需内尿停滞がかなり高 い関連性をるつことの裏付となる。

立位に際しての腎下垂の程度と滞尿腎の遭遇頻度との 間には，第13表に示す如く，特別な関係がない。

Narath 氏症候 : Narath は緊張の低下した筒孟・腎 杯では，立位影響の際に造影剤が腎孟・腎杯腔の下部に 沈下して描出されるといつて，これが遊走腎における腎 盘内尿停滞を示す症候として重視している．私らの研究 対象例で Narath 氏症候陽性者の頻度を調べてみたが， 仰臥位に括ける腎衁像中心の位置や立位に和ける腎下垂 第13表＼cjkstart立位に際しての腎の下垂の程度と腎孟 尿停滞の頻度

\begin{tabular}{|c|c|c|}
\hline $\begin{array}{c}\text { 腎下垂 } \\
\text { の程度 }\end{array}$ & 正常者 & $\begin{array}{c}\text { 尿停滞気味に } \\
\text { る者 } 1\end{array}$ \\
\hline 1 椎骨高以内 & 155 & $20(14.3 \%)$ \\
\hline 2 椎骨高 & 112 & $14(12.5 \%)$ \\
\hline $\begin{array}{c}2 \text { 椎骨高を } \\
\text { 越えるもの }\end{array}$ & 11 & $2(15.4 \%)$ \\
\hline
\end{tabular}

の程度の如何にかかわらずこれを認めないものが大部分 であり，僅に男子70例中13例，女子 239例中29例，併せ て 309例の立位撮影施行例中42例（13.6\%）にこれを見 たに過ぎない。この42例中上に述べた程度の腎盘桩張 (尿停滞) を認めたものは 6 例 $(14.3 \%)$ のみである.

要之，Narath 氏症候は腎固定術の適応症決定の上に は考虑さるべさ所見であるが，遊走腎に於て Narath 氏 症候をあらわすような腎盘弛緩を来すことは少いもので あることが注目せられる。

\section{考案}

Kelly and Burnam (1914) 或は Mathé (1925) の 頃から，生理的範囲を越えて動く腎が遊走腎であるとい ら定義が通用している。しかし，「生理的な正常な範囲」 というものについてははつきりした基準が与えられてい ない，腎位置を論ずる上に的確な腎而像による研究をみ ると, Thomas (1925), Woodruff and Scherer (1936), Birdsal（1936）など，腎盂像と腰椎骨の位置的関係か ら腎下垂の程度を分類はしているが，そのどこからが病 的なのかについては敢て述べていない. Kaminsky らは 立位での腎の $5 \mathrm{~cm}$ な゙の下降は正常のことだとしてい る.この長さを本邦人に換算して当てはめてみると 1 椎 骨高又はそれを多少上迴る程度の下垂ということにな る. 本邦では並木・山之内は正常な本邦人の仰臥位深吸 気時の腎盘下極は第 2 第 3 腰椎間にありという研究成績 を発表しており，佐谷は健康者の腎典の位置の下極限は 第 3 腰椎であつて，これより低いものを病的とみなすべ きだといつている．吉川は立位で腎盂下端が第 4 腰椎中 央以下にあるものを遊走腎としている . 私らのフィルム では 1 椎骨高（相隣る腰椎骨の同じ部分間の距離）は 5.5〜 4.0 cmであり,腎血像長軸(上腎杯から下腎杯に亘 る距離）の脊柱への投射の長さは凡そ 4.5〜 8.0 cmであ るから吉川の基準を腎需中心の位置について置き換える と，それが第 3 腰椎の中心を越えて下垂するるのを遊走 腎としているようである。これらの諸説は一と先ず正常 
な腎位置というものを述べている如くである。私らは遊 走腎の診断について検討するに当り，生理的正常な腎位 置をはつきりとつかまえる必要を感じ，腎孟像の中心を 腎位置を示す示標として多くの症例について研究したの である。その結果, 仰臥位吸気時には腎孟中心は右側で は第 2 腰椎のいずれの高さにかかつて拉り，左側ではせ れより高々 $1 / 2$ 椎骨高だけ上位にあり，立位では男子では 両側共に,女子では左側に於て 1 椎骨高下垂すること,換 言すれば，これらの場合，右側では第 3 腰椎の高さにか かり，左側ではこれよりはやや高い位置にあるといらの が大多数の人に当てはまる正常な生理的な位置であるこ とを確認した。これは佐谷や Kaminsky の示した基準 と一致するものである。ただ，女子の右側では，立位に 際して $1 \frac{1}{2}$ 椎骨の下垂即ち立位で腎孟中心が第 4 腰椎の 上 $1 / 3$ にかかるものも，腎下垂の点だけからいえば敢て病 的とはい党ないということが知られた。

腎長軸の脊柱に対する傾斜については本邦人について 並木・山内の仰臥位に和ける研究があるが，立位に怙け るそれを計統的に研究したものは私らの得た文献中には 見当らないので，この点を研究してみた。その結果，仰 臥位では腎長軸は脊柱に対し下側に $20^{\circ}$ の角をとるのが 多数例にみられるの正常な状態であつて一と先ずの基準 とすることができる．立位をとるときは腎は下垂すると 共に自然に腎茎起始部を中心として腎茎を半径とした円 周上を迴転するものであるから腎長軸の脊柱に対する傾 斜角は減少するのが当然である，その度合については腎 床の大さ，腎周囲組織の粗密にしたがつてのかなりの動 摇がある。左側では立位に変換した際の傾斜角の変化が 少く，脊柱と平行の状態にまではなるが，それを越えて 上方に開いた角（負の角と呼んだ）をとることはない。 右側では負の角をとることは少くないが，それもー200 以内に止るものが大部分であつて，ここに正常，生理的 という限界を执くことができる。腎が立位をとるとき は，更に，腎茎を軸とした迴転を来たするのであり，生 理的に正常な状態はその迴転は $35^{\circ}$ までということがで きる。

以上のことから，腎の位置関係からいえば，立位にて 仰臥位に打梳るり 1 椎高以上腎の下垂を来たす場合， 渙言すれば右腎についていつて，腎盂像の中心が第 3 腰 椎を越觉る場合，立位に护ける腎長軸が左側にて脊柱と 上に開いた角を㣣み，右側にては脊柱と上に開いた $20^{\circ}$ 以上の角度を挾むに至つた場合，立位に扔いて腎が腎茎 の廻りに $35^{\circ}$ 以上の迴転をする場合を，病的な腎下垂或 は遊走腎と定義することができる：ただ腎の位置につい ては，女子の右側では腎孟中心が仰臥位より $11 \frac{1}{2}$ 椎骨高
までの下垂は特に病的と考えなくてもよい。

腎下垂の程度と症状の発現ないしは乞の強弱は関連性 のないものが少くないことは万人の認める所である．腎 下垂や迴転が著しいのに何らの症状を訴えることなく， また腎孟腎杯に形態的変化なく腎機能の正常なものが少 くないのであつて，このことは腎固定術の適反応を選ぶ 上飞，単なる遊走腎か遊走腎症なるかを見極める必要性 の説かれる所以である。私らは，この辺の消息をさぐる 試みとして，正常者の腎下垂者に㧸ける症状発現の頻度 を比較してみた。それによると病的な腎下垂者では，正 常者よりも症状発現者の頻度が 2 倍ないし 3 倍は多いこ とを知つた。しかし，個々の人の症状が明らかに病的な 腎下降によることを常に確実ならしめる方法は未だ見出 し得なかつた。

遊走腎の診断は単に遊走腎そのものを診断するのでは なく，それが手術適応症であるかどうかについて下され ねばならない。これには症状の有無と同椂に，重大な合 併症をもつか否かが問題となる．上部尿路感染と上部尿 路停滞（水腎）とについて述べた。この両者は相関連し た病変であり，尿停滞がなければ感染は起り難く，また 尿停滞が除去されれば感染は扔のずから除去されるもの であある．したがつてその主役は上部尿路停滞の演ずる 所となる。腎下垂に和ける水腎の発生頻度については， 水腎の程度をどのように批判するかによつて，文献上の 数値にかなりの差がある。また，水腎の発生原因を単に 腎下垂のみと解釈するか，尿管上部の結合織索や異常血 管の圧迫・絞拒というょうな併存する原因を含めて数兄 上げるかどうかによつても数が異り，Birdsal の遊走腎 150例中 81 例 $(54 \%)$ から, Kelly の61例中 8 例（13.1 \%) といら開きがみられる。南は74例の遊走腎の21例 （28\%）に水腎をみたが大部分軽微であつたといつてい る。Crabtree et al。は常時ではないが，一旦起した腎 孟炎の全治し得ない程頑因に尿流を阻害することのある ことを警告している。私らの検討した 323例の腎下垂者 ではその $13.3 \%$ に部尿路停滞者をみたに過ぎず，しか もその大部分は腎孟に多少の拡張をみた程度であつて腎 杯には停滞像がなく，7例のみに私らの評価の $\mathrm{A}$ 程度の 水腎をみたに過ざない。しかし少許とはい党尿の停滞を 来すとい・うことは一旦起つた上記尿路感染の除去を長引 かせ，腎孟腎炎への進展の機会を与えるものであるから ゆるがせには出来ない. Woodruff et al.は腎孟の尿停 滞の読影の際，経静脈性腎孟撮影法で腎孟腎杯に拡張の みられる場合には逆行性腎孟撮影法によつて同程度の拡 張のみられる場合よりも事は重大であり，また経静脈性 腎孟撮影法によつて 腎監杯の拡張がないからといつ 
て，それ丈で腎盂への尿停滞ないし拡張が実際に起つて いないと考えてはならないと警告している.しかし,私ら は，無圧性経静脈性腎孟撮影法によつて腎孟腎杯に拡張 像がなければ，その際張性と運動性は十分にあるものだ と解釈している。腎盂拡張と腎盂壁の弛緩は相伴うのが 普通であつて，後者を有無を知ることも遊走腎の診断上 重要なことである。これが screening として Narath 氏 症候は一つの指針を与兄る. 私らの立位撮影を施行 309 例中本症候をみたものは13.6\%であつた，尿停滞の有無 を知るにはその他遅延性腎孟撮影法(delayed filming), X線映画法 (cinefluorography), 上部尿路内圧計測法 (manometry) があるが, 私らは内圧測定法により若干 の知見を得ているが，これについては著者の一人伊藤が 他日記述する。

内蔵下垂と腎下垂の関係については, 私らは, 胃下垂 を代表として検討し, 病的な腎下垂者の半数には胃下垂 が併存しているのを知つた。

腎下垂を捕捉する手段としては腎孟撮影法が最もよ い。そして, 生理的自然な状態を描出するには無圧性経 静性腎孟撮影法が最もよいが，本法では立位撮影によつ て余り良好な腎孟尿管像が得られない欠点がある.私ら は立位無圧性ivp で十分診断に役立つ方法について研究 を行つていたが, Maxwell の rapid sequency pyelography を立位のままに施行して，その目的を十分に達 する腎孟像を得たことにヒントを得て, 造影剂注射後, 先ず 5 分で立位撮影を行い, 然る後仰臥位撮影を行らこ とにより，この方法の施行例の約 $80 \%$ に満足のいく写真 を得るようになつた。遊走腎の診断にはこの撮影法を椎 奖するものである。

\section{結 論}

生理的に正常な腎の位置を知る目的で，腎盂像につい て統計的な研究を行い次の結論を得た。

1.474例の仰臥位に和ける腎孟像についてみると， 男女共に右側では腎孟の中心が第 2 腰椎のいずれかの高 さにあるのが正常生活的な基準であり，左側ではこれと 同高か或は高々 $1 / 2$ 椎骨高丈高い。

2.163例についてみるに立位をとると，腎孟中心は 男女共に左側では 1 椎骨高下垂し, 右側では男子は 1 椎 骨高，女子では $111 / 2$ 椎骨高をでは下垂するのが生理的正 常な状態と考兄られる。

3. 腎長軸の脊柱に対する傾斜角は男女左右共に $20^{\circ}$ （下方に向いて角を狭む）といらのが生理的正常の基準 である。

4. 立位をとると，(3)の傾斜角は両側共に減少する のが通常である。左側では男女共 $0^{\circ}$ （脊柱に平行）に
坐るまでの変化をとり，それを越えて負の解をとること （腎長軸が脊柱と上方を向いた鋭角を㣣むこと）のない のが生理的正常な状態である。右側では傾斜の変化は左 側よりも動摇範囲が大きく，負の角をとるものも少くな い。しかし負の角一 $20^{\circ}$ までが正常生理的な範囲と考克 られる。

5。立位に拈ける腎の腎茎周囲の迴転は，35゚ までが 正常生理的範囲である。

6. したがつて上述の各生理的基準を逸脱したものを 遊走腎を考学るのが妥当である。更に尿管起始部の上行 屈曲も考慮すべきことはいうまでもない。

7. 遊走腎者どは正常者に乱けるより，腹痛・腰痛を 訴兄る頻度が $2 \sim 3$ 倍に多い。

8. 更に合併症併発症として胃下垂, 上部尿路感染及 び腎盃尿停滞（水腎）について述べた。遊走腎の半数に は胃下垂が併発している．遊走腎者の方が正常者より上 部尿路感染を来たすことが多い. 腎孟の尿停滞は 323例 の腎下垂者の $13.3 \%$ みられたが且軽微なものであつて私 らの分類による $\mathrm{A}$ 程度水腎は $2 \%$ 遭遇されたにすぎな い. Narath 氏症候は13.6\%にみられた。

9. 遊走腎の診断には無圧迫性経静脈性腎孟撮影法を 用いるのが最もよい. 本法施行に当つては造影剂注射後 5 分で先ず立位撮影を行い，その後仰卧位撮影法を施行 することによつて対象例の約 $80 \%$ に両体位共に診断上十 分満足な腎孟像が得られる。

〔本論文の一部は第 55 回日本泌尿器科学会総会のシン ポジゥムで岡が述べた」

\section{交献}

1) Birdsall, J.C.: J. Urol. 35, 135, 1936.

2) Crabtyee, E.G. and W.M. Shedden : J. Urol. 6, 207, 1921.

3) Kaminsky, R. and E. Hess: J. Urol. 69, $21,1953$.

4) Kelly, H.A. and C.F. Burnam : 南原著より引 用。

5) Mathé, C.P.: Surg. Gyn. \& Obst. 40, 605, 1925.

6) Maxwell, M.H., H.C. Gonick, R. Wiita and J.J. Kaufman: New Engl. J. Med, 270, 213, 1964.

7）南武：遊走腎症，日泌尿全書。2, II, 金原出版。 昭和36 (1961)。

3）並木重郎・山之内秀三：日泌尿会誌。31，1332, 昭和 6 (1931)。

9) Narath, A.: Urol. internat. 6, 1, 1958 .

10）佐谷有吉：日皮尿会誌, 21, 151, 大正10 (1921)。

11) Thomas, B.A.: J. Urol. 22, 603, 1929.

12) 吉川康史 : 名古屋医学, 70, 838, 昭和30 (1955).

13) Woodruff, S.R. and R.G. Scherer: J. Urol。 $35,125,1936$.

（昭和42年 9 月11 日受付） 